\title{
Quality of dwarf cashew tree seedlings as a result of methods for breaking dormancy, container volume and application of bovine biofertilizer
}

\section{Calidad de plántulas de cajueiro enano como resultado de métodos de rompimiento de dormancia, volumen de matera y aplicación de biofertilizante bovino}
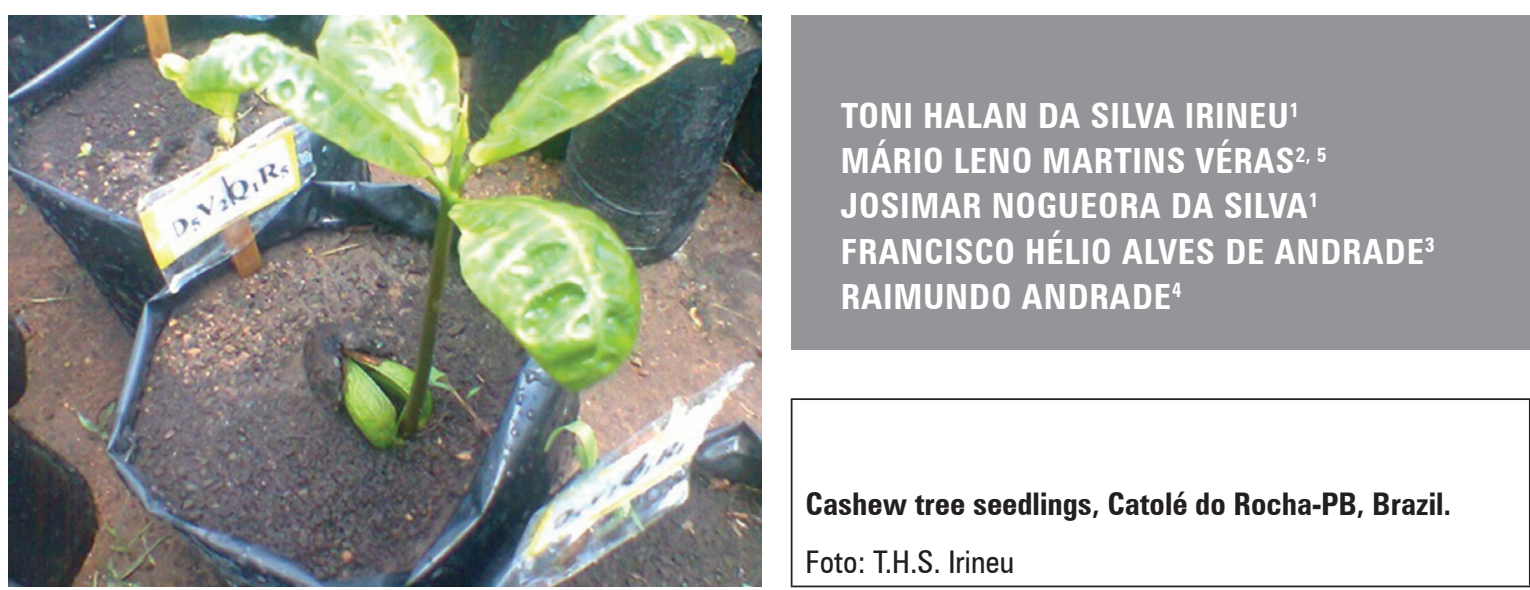

\begin{abstract}
The dwaf cashew tree presents enormous economic relevance for the Brazilian northeast. When establishing orchards of this species, the most important phase is the formation of the seedlings. Therefore, studies aiming to improve growth aspects and seedling qualities are extremely relevant. In this sense, the present study aimed to evaluate the growth and quality of dwarf cashew tree seedlings as a result of methods for breaking dormancy, container volume and application of bovine biofertilizer. The experiment design was completely randomized, with a $2 \times 2 \times 5$ factorial scheme and six replicates; the experimental unit consisted of five seedlings. The treatments involved two methods of breaking dormancy (scarification with sandpaper and immersion in water), two container volumes (1 and $2 \mathrm{~kg}$ ) and five doses of bovine biofertilizer (0, 2.5, 5.0, 7.5 and $10 \mathrm{~mL}$ ). The method for breaking dormancy with normal water for 24 hours was the most adequate for the formation of dwarf cashew tree seedlings. The doses of 7.5 and $10 \mathrm{~mL}$ of bovine biofertilizer provided higher growth and quality in the dwarf cashew tree seedlings. The volume of $2 \mathrm{~kg}$ of substrate was the most suitable volume for growing dwarf cashew trees.
\end{abstract}

1 Federal University Rural Semiarid, Department of Plant Science, Mossoró (Brazil). ORCID Irineu, T.H.S: 0000-00034628-5833; ORCID Silva, J.N.: 0000-0001-9508-5526

Federal University of Viçosa, Department of Plant Science, Viçosa (Brazil). ORCID Véras, M.L.M.: 0000-0001-59684564

3 Federal University of Lavras, Department of Plant Physiology, Lavras (Brazil). ORCID Andrade, F.H.: 0000-0002-96991413

4 State University of Paraíba, Department of Agrarian and Exact, Catolé do Rocha (Brazil). ORCID Andrade, R.: 00000002-0295-468X

5 Corresponding author. mario.veras1992@gmail.com 
Additional key words: Anacardium occidentale L.; propagation by cuttings; dormancy breaking; biofertilizers; fruits.

\section{RESUMEN}

El cajueiro presenta enorme relevancia económica para el Nordeste Brasileño. Para el establecimiento de huertos de esta espécie, la fase más importante es la formación de plántulas. Por esto, estudios para mejorar aspectos de crecimiento y calidad de plántulas son de gran importancia. En tal sentido, el objetivo del presente trabajo fue evaluar el crecimiento y calidad de plántulas de cajueiro en respuesta a métodos de rompimiento de dormancia, volumen de la matera y aplicación de biofertilizante bovino. Se utilizó el diseño experimental completamente al azar con arreglo factorial $2 \times 2 \times 5$, seis repeticiones y la unidad experimental de cinco plántulas. Los tratamientos consistieron en dos métodos de rompimiento de dormancia (escarificación por lija e inmersión en agua), dos volúmenes de matera (1 y $2 \mathrm{~kg}$ ) y cinco dosis de biofertilizante bovino $(0 ; 2,5 ; 5,0 ; 7,5$ y $10 \mathrm{~mL})$. El método de rompimiento de dormancia con agua normal durante 24 horas fue el más adecuado para la formación de plántulas de cajueiro. Las dosis 7,5 y 10,0 $\mathrm{mL}$ de biofertilizante bovino proporcionaron mayor crecimiento y calidad de plántulas de cajueiro. El volumen $2 \mathrm{~kg}$ de sustrato fue el volumen más indicado para el cultivo de plántulas de cajueiro.

Palabras clave adicionales: Anacardium occidentale L.; propagación por esquejes; salida de latencia; biofertilizante; fruticultura.

Received for publication: 21-07-2018 Accepted for publication: 29-03-2019

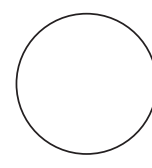

The cashew tree (Anacardium occidentale L.) is one of the most cultivated fruits in the Brazilian, northeastern semi-arid region, presenting an important crop in the generation of employment and income since it has high use potential, both for fresh consumption of pseudofruit and for processing (Araújo et al., 2014; Silva et al., 2019).

During the formation of orchards of this species, the seedling formation phase significantly contributes to the costs. Germination is a very important factor in the process of seedling formation since many species' present dormancy. Dormancy consists of the phenomenon in which the seeds of a certain species, even if they are viable and have favorable environmental conditions for germinating, stop doing so (Costa et al., 2010; Carvalho et al., 2019).

The methods most used to breaking seed dormancy include scarification (Ursulino et al., 2019) and immersion, which are more practical and safer methods for small farmers who desire seedlings in a short period of time. Since the cashew presents dormancy, studies on methods for breaking dormancy are extremely relevant (Mata et al., 2010). Therefore, it is necessary to seek more efficient methods to breaking dormancy, which is a point of paramount importance for the formation of seedlings with high quality.

Also, seedling producers face uncertainty in the choice of containers for the production of seedlings. The size of the appropriate container is an important aspect as it may influence the health of the seedlings. Studies with container volumes have shown that the volume of $2 \mathrm{~L}$ of substrate influences the vegetative and quality behavior of the guava and pineapple (Paiva et al., 2013; Diniz et al., 2015).

In the formation of fruit orchards, the most important step is the seedling formation phase. This phase is very demanding in terms of nutrients; therefore, fertilizer alternatives are extremely relevant because well-formed seedlings influence the quality of the orchard. Many seedlings have been using bovine biofertilizer because of the rapid absorption, making it very useful for annual and perennial crops in conventional and organic systems or in rapid treatments of nutritional deficiencies in plants. 
Bovine biofertilizer has been used as a way to meet the nutritional needs of macro and micronutrient plants and organic matter; in addition, when biofertilizer is applied in liquid form, it provides greater displacement of nutrients in the soil, facilitating absorption by plant roots, thereby promoting better initial growth (Dutra et al., 2018; Melo Filho et al., 2018; Alves et al., 2019). According to Sá et al. (2013), biofertilizer, when applied via the soil, favors the activity of microorganisms and promotes better nutrient availability to the roots.

In addition to be a product rich in nutrients that are essential for plants, the bovine biofertilizer is lowpriced and easily prepared by small farmers. Some studies with biofertilizers have shown positive results, being able to attenuate possible nutritional deficiencies and favor the growth of plants in the phase of seedling production (Sá et al., 2013; Diniz et al., 2015; Alves et al., 2019).

Because of the scarcity of studies on early dwarf cashew tree seedlings, the present study aimed to evaluate the growth and quality of cashew tree seedlings as a result of methods for breaking dormancy, container volumes and application of bovine biofertilizer.

\section{MATERIAL AND METHODS}

This experiment was conducted in 2017, for a period of $71 \mathrm{~d}$ in a protected environment, with $50 \%$ shading, at the State University of Paraiba - UEPB, Campus-IV, municipality of Catole do Rocha-PB, Brazil, located geographically at latitude $6^{\circ} 20^{\prime} 38^{\prime \prime} \mathrm{S}$ and longitude $37^{\circ} 44^{\prime} 48^{\prime \prime} \mathrm{O}$ with an altitude of $275 \mathrm{~m}$, with a monthly average temperature above $18^{\circ} \mathrm{C}$.

The experiment design was completely randomized, with a $2 \times 2 \times 5$ factorial scheme and six replicates; the experiment unit consisted of five seedlings. The treatments consisted of two methods of breaking dormancy (scarification with sandpaper and immersion in water), 2 container volumes $\left(1\right.$ and $\left.2 \mathrm{dm}^{3}\right)$ and five doses of bovine biofertilizer (0, 2.5, 5.0, 7.5 and $10 \mathrm{~mL})$.

The seedlings were cultivated in containers filled with earthworm humus and soil classified as Eutrophic Flubic Neosol (Santos et al., 2013), which had the following characteristics: $\mathrm{pH}\left(\mathrm{H}_{2} \mathrm{O}\right)=6.85$; nutrients $\left(\mathrm{cmol}_{c} \quad \mathrm{dm}^{-3}\right): \quad \mathrm{Ca}^{2+}=2.10, \mathrm{Mg}^{2+}=1.07$, $\mathrm{Na}^{+}=3.73, \mathrm{H}=0.13, \mathrm{Al}^{+3}=0.01$, cation exchange capacity $=5.94$, base sum $=5.8 ; \mathrm{K}^{+}=0.01 \mathrm{mg} \mathrm{dm}^{-3}$; organic carbon $=4.55 \%$; organic matter $=7.85 \%$; assimilable phosphorus $=8.31 \mathrm{mg} / 100 \mathrm{~g}$; soil texture $\left(\mathrm{g} \mathrm{kg}^{-1}\right)$ : sand $=63.90$, silt $=20.65$ and clay $=15.45$; apparently density $=1.41 \mathrm{~g} \mathrm{~cm}^{-3}$; field capacity humidity $=11.23$ $\mathrm{g} \mathrm{kg}^{-1}$; permanent wilting point humidity $=6.56 \mathrm{~g} \mathrm{~kg}^{-1}$ and textural class =sandy loam; the soil was analyzed according to the procedures described in the methodology of Santos et al. (2013).

The worm humus had the following characteristics (meq/100 g): $\mathrm{Ca}=35.40, \mathrm{Mg}=19.32, \mathrm{Na}=1.82$, $\mathrm{K}=1.41, \mathrm{~S}=57.95, \mathrm{H}=0.00, \mathrm{Al}=0.00, \mathrm{~T}=57.95$, qualitative calcium carbonate $=$ present and assimilable phosphorus $=55.14$. Others: $\mathrm{pH} \mathrm{H}_{2} \mathrm{O}(1: 2.5)=7.38$, eletric conductivity $(\mathrm{EC})=2.11 \mathrm{dS} \mathrm{m}^{-1}$.

The breaking of the dormancy in the cashew nuts was accomplished with two methods (scarification with sandpaper and immersion in water for $24 \mathrm{~h}$ ). After treatments for dormancy, the cashew nuts were sown directly in two-pack polyethylene bags (type 1 : $18 \times 22 \mathrm{~cm}$ and type $2: 22 \times 30 \mathrm{~cm}$ ), containing 1 and $2 \mathrm{dm}^{3}$ of substrate, respectively.

For the production of the bovine biofertilizer, the methodology of Silva et al. (2012) was used. The applications of the bovine biofertilizer were done $30 \mathrm{~d}$ after the emergence of the plants in the container, 7 to $7 \mathrm{~d}$ apart, applying biofertilizer doses $(0,2.5,5.0$, 7.5 and $10 \mathrm{~mL} /$ plant) directly under the substrate of each container, with a total of six applications.

The bovine biofertilizer had the following chemical characteristics: $\mathrm{pH}=5.27, \mathrm{EC}=4.81\left(\mathrm{dS} \mathrm{m}^{-1}\right) ; \mathrm{N}=1.30$ $\left(\mathrm{g} \mathrm{kg}^{-1}\right) ; \mathrm{P}=537.0\left(\mathrm{mg} \mathrm{dm}{ }^{-3}\right) ; \mathrm{S}=9.55\left(\mathrm{mg} \mathrm{dm}^{-3}\right)$; $\mathrm{Na}=2.47\left(\mathrm{cmol}_{c} \mathrm{dm}^{-3}\right) ; \mathrm{K}=1.34\left(\mathrm{cmol}_{c} \mathrm{dm}^{-3}\right) ; \mathrm{Ca}=3.00$ $\left(\mathrm{cmol}_{c} \mathrm{dm}^{-3}\right)$ and $\mathrm{Mg}=4.45\left(\mathrm{cmol}_{c} \mathrm{dm}^{-3}\right)$.

At $71 \mathrm{~d}$ after sowing, six plants were sampled per treatment for determinations of: height $(\mathrm{cm})$ from lap bud to apical bud; stem diameter ( $\mathrm{mm}$ ); measured at a distance of $2.0 \mathrm{~cm}$ from the neck, using a pachymeter with an accuracy of $0.01 \mathrm{~mm}$; number of leaves; root length, measured with a stepwise ruler in $\mathrm{cm}$; and leaf area, where the leaves were considered to have a minimum length of $1.0 \mathrm{~cm}$, measuring the leaf's main leaf length $\mathrm{x}$ width $\mathrm{x}$ adjustment factor (0.60) (Peixoto and Peixoto, 2009). The total leaf area was determined by multiplying the leaf area by the number of leaves. 
Subsequently, the vegetative parts were separated and placed in paper bags and subjected to forced air circulation in an oven for $48 \mathrm{~h}$ at a temperature of $60^{\circ} \mathrm{C} \pm 1.0$ until constant mass was obtained and then weighed on an analytical balance with an accuracy of $0.0001 \mathrm{~g}$, with the results expressed in grams. The difference between the fresh mass and dry mass provided the constant dry mass of the plants. At the end of the experiment, the Dickson Quality Index (DOI) was determined (Dickson et al., 1960).

The data were analyzed and interpreted with analysis of variance (Test F) and comparison of averages with the Tukey test, following Ferreira (2014), with a minimum significance of $5 \%$ probability. The analyses were performed with SISVAR statistical software v 5.0 .

\section{RESULTS AND DISCUSSION}

It was observed that the interaction between the factors did not present a significant difference. The studied pot volumes statistically influenced the height, root length and leaf area of the seedlings. The methods for breaking dormancy did not influence the analyzed variables. The doses of bovine biofertilizer significantly influenced all variables.

It was observed that the height of the cashew seedlings was positively influenced by the doses of bovine biofertilizer, presenting a quadratic polynomial behavior, with higher values in height $(17.36 \mathrm{~cm})$ in the seedlings treated with $10 \mathrm{~mL}$ of bovine biofertilizer, with an increase of $14.17 \%$ in relation to the seedlings that did not receive application of bovine biofertilizer (Fig. 1A).

The results corroborate those found by Veras et al. (2014) who, when evaluating the growth of cashew tree seedlings subjected to doses of biofertilizer and substrate volumes, observed that the cashew had a higher yield under the application of biofertilizer at a dose of $120 \mathrm{~mL}$.

The doses of biofertilizer provided a significant difference for stem diameter $(P \leq 0.01)$, and the regression equation adjusted to the experiment data presented a quadratic polynomial model, in which, as the doses of biofertilizer were increased, there was an increase in diameter, with the highest value of $6.08(\mathrm{~mm})$ obtained with the dose of $10 \mathrm{~mL}$ (Fig. 1B).
These values are higher than those obtained by Costa et al. (2012), who evaluated the growth of cashews irrigated with domestic effluent and verified that the diameter of the seedlings was not influenced by the wastewater, presenting $1.0(\mathrm{~cm})$, statistically equal to that found in those irrigated with a water supply (control), values lower than those found in the present study.

The number of leaves presented a quadratic behavior, with a statistical significance $(P \leq 0.01)$, obtaining a higher value (14 leaves) in the seedlings that received an application of $7.5 \mathrm{~mL}$ of bovine biofertilizer; as the biofertilizer dose was increased, there was a decrease in leaf number of 0.0224 with the recommended optimum dose of 7.5 (Fig. 1C).

This result is greater than that obtained by Costa et al. (2012) when studying cashew tree seedlings irrigated with domestic effluent, which obtained 13 leaves, found in the highest percentage of residual water.

The highest number of leaves is a result of the positive effect of the bovine biofertilizer, which may have stimulated the release of humic substances and, consequently, released nitrogen and carbon, as well as the high percentage of cation exchange capacity in the soil, thus favoring the absorption of essential nutrients (Cavalcante et al., 2007; Viana et al., 2013).

The root length showed a regression equation with respect to the effect of bovine biofertilizer doses, with an increasing linear behavior. Notably, the most marked growth was observed in the treatment with the dose of $10 \mathrm{~mL}$, presenting an increase of $18.91 \%$ in relation to the control. Raising the dose showed an increase of 0.4112 in root length (Fig. 1D).

It is possible that the greater root expansion of the saplings treated with biofertilizer was due to the physical improvement provided by the humic substances present in the bovine biofertilizer (Aidyn et al., 2012). In passion fruit seedlings, Cavalcante et al. (2009) and Mesquita et al. (2012) observed that the seedlings showed superiority in root development when the seedlings were fertirrigated with bovine biofertilizer.

It was observed that leaf area was influenced by the doses of biofertilizer; the maximum value obtained was $28.49 \mathrm{~cm}^{2}$ with the dose of $7.5 \mathrm{~mL}$ of bovine biofertilizer; as the doses of biofertilizer increased, there was a decrease (-0.0601) in the leaf area of the cashew tree seedlings (Fig. 1E). With an increase in leaf area, 


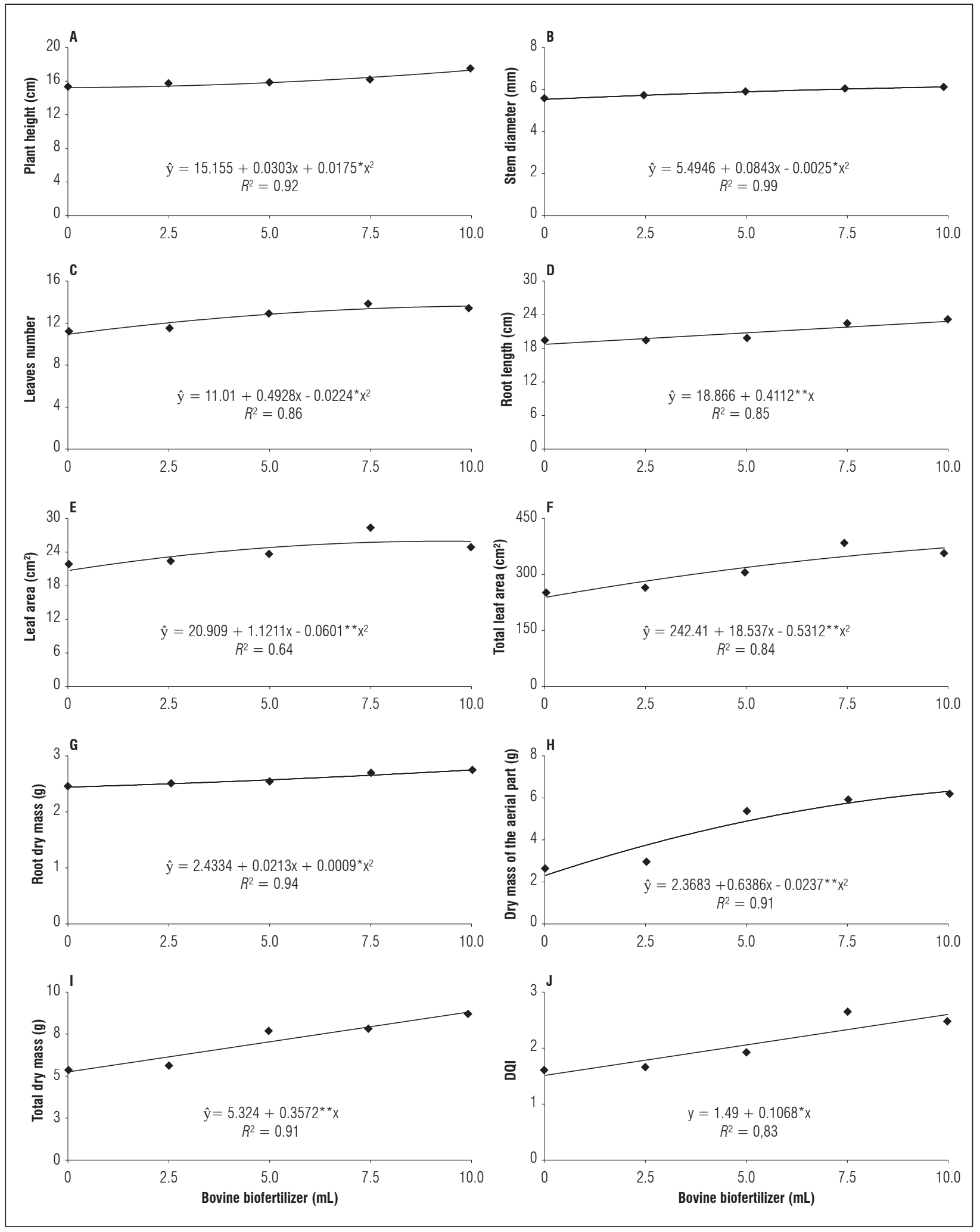

Figure 1. Height (A), stem diameter (B), number of leaves (C), root length (D), leaf area of seedling (E), total leaf area (F), root dry mass (G), dry mass of the aerial part (H), total dry mass (I) and Dickson Quality Index (J) of cashew tree seedlings submitted to doses of bovine biofertilizer. 
there is greater efficiency in plants in the photosynthetic processes, as well as in the transport of solutes in the vegetal tissues. These results corroborate those obtained by Mesquita et al. (2012) for papaya seedlings and by Cavalcante et al. (2007) for guava seedlings.

The total leaf area presented a significant effect $(P \leq 0.01)$, showing a quadratic polynomial behavior; the dose of $7.5 \mathrm{~mL}$ provided a larger leaf area $(386.56$ $\mathrm{cm}^{2}$ ), and, beyond that dose, there was a decrease of -0.5312 in total leaf area $\left(\mathrm{cm}^{2}\right)$ (Fig. 1F).

The dry mass of the root was influenced by the doses of biofertilizer at the level of $P \leq 0.01$, presenting an increasing quadratic polynomial model. The maximum values were obtained with the dose of $10 \mathrm{~mL}$, observing that, as the doses of bovine biofertilizer rose, an increase in root dry mass (Fig. 1G) was observed. The results obtained in the present study corroborate those obtained by Veras et al. (2014), who, when evaluating different doses of biofertilizer in the development of cashew seedlings, obtained the best results with the highest doses of biofertilizer for most of the analyzed variables.

The biofertilizer doses provided a significant difference for the dry mass of the shoot at the level of $(P \leq 0.01)$, presenting a quadratic behavior. As the doses of bovine biofertilizer increased, there was an increase of 31.22 between the doses of 0 to $100 \mathrm{~mL}$ (Fig. 1H).
The results presented in this research were $6.22 \mathrm{~g} /$ plant, which corroborate the data obtained by Torres et al. (2014), who found similar results where the use of bovine biofertilizers promoted increases in the fresh mass of the aerial part of seedlings irrigated with water.

The regression equation adjusted to the experiment data of total dry mass presented a linearly increasing behavior, and a significant effect was observed at $P \leq 0.01$ for the biofertilizer doses. The dose of 10 $\mathrm{mL} /$ plant-time gave the best results in total dry mass, which was 8.75 (g/plant), presenting an increase in relation to the control of $62.33 \%$ (Fig. 1I).

The Dickson Quality Index (DOI) was statistically influenced $(P \leq 0.01)$ by the Tukey test; the regression equation adjusted to the DOI data presented a quadratic behavior. The application of the $7.5 \mathrm{~mL} /$ plant-time dose gave satisfactory results; when the dose was increased, there was a decrease in the DOI, with a maximum value of 2.58 (Fig. 1J).

There was a significant difference between the means of the treatments of volumes for plant height, root length and leaf area of the dwarf cashew seedlings in relation to the containers used.

The increments were 6.46, 26.52 and $11.74 \%$ for plant height, root length and leaf area of the seedling, respectively, with the use of the $1 \mathrm{~kg}$ container in relation to the volume of $2 \mathrm{~kg}$ of substrate in polyethylene plastic bags. In the other analyzed variables,

Table 1. Estimated growth averages of dwarf cashew seedlings with two container volumes $\left(V_{1}\right.$ and $\left.V_{2}\right)$ and methods for breaking dormancy $\left(S_{1}\right.$ and $\left.S_{2}\right)$.

\begin{tabular}{|c|c|c|c|c|c|}
\hline \multirow{2}{*}{ Variable } & \multicolumn{2}{|c|}{ Container volumes } & \multicolumn{2}{|c|}{ Dormancy breaking } & \multirow[t]{2}{*}{ LSD } \\
\hline & $V_{1}$ & $V_{2}$ & $\mathrm{~S}_{1}$ & $\mathrm{~S}_{2}$ & \\
\hline Height (cm) & $15.46 b$ & 16.46 a & $15.90 \mathrm{a}$ & $16.02 \mathrm{a}$ & 0.35 \\
\hline Stem diameter (mm) & $5.74 \mathrm{a}$ & $5.90 \mathrm{a}$ & $5.73 a$ & $5.93 \mathrm{a}$ & 0.07 \\
\hline Leaves number & $12.61 \mathrm{a}$ & 12.65 a & $12.20 \mathrm{a}$ & 13.07 a & 0.34 \\
\hline Root length (cm) & $18.47 \mathrm{~b}$ & 23.37 a & $20.10 \mathrm{a}$ & $21.74 \mathrm{a}$ & 0.65 \\
\hline Leaf area $\left(\mathrm{cm}^{2}\right)$ & $22.91 \mathrm{~b}$ & $25.60 \mathrm{a}$ & $23.71 \mathrm{a}$ & $24.80 \mathrm{a}$ & 0.71 \\
\hline Total leaf area $\left(\mathrm{cm}^{2}\right)$ & $296.68 \mathrm{a}$ & $333.68 \mathrm{a}$ & $296.83 \mathrm{a}$ & $333.52 \mathrm{a}$ & 13.23 \\
\hline Root dry mass (g) & $2.56 \mathrm{a}$ & $2.59 \mathrm{a}$ & $2.55 \mathrm{a}$ & $2.59 \mathrm{a}$ & 0.02 \\
\hline Dry mass of the aerial part $(\mathrm{g})$ & $4.64 \mathrm{a}$ & $4.71 \mathrm{a}$ & $4.65 a$ & $4.71 \mathrm{a}$ & 0.03 \\
\hline Total dry mass (g) & $6.92 \mathrm{a}$ & $7.30 \mathrm{a}$ & $6.95 \mathrm{a}$ & $7.27 \mathrm{a}$ & 0.16 \\
\hline Dickson Quality Index & $1.94 \mathrm{a}$ & $2.06 \mathrm{a}$ & $1.97 \mathrm{a}$ & $2.03 \mathrm{a}$ & 0.07 \\
\hline
\end{tabular}

Means followed by the same letter do not differ according to the Tukey test $(P \leq 0.05) . V_{1}=1 \mathrm{~kg} ; V_{2}=2 \mathrm{~kg} ; \mathrm{S}_{1}=$ scarification with sandpaper; $S_{2}=$ immersion in water. LSD = Least significant difference value. 
it was observed that, although they did not present a significant effect for the volume, it was possible to notice that the substrate volume of $2 \mathrm{~kg}$ was higher than the substrate volume of $1 \mathrm{~kg}$ (Tab. 1).

The data found in the present study corroborate those of Veras et al. (2014), who studied the effect of substrate volumes on the development of cashew tree seedlings and observed that the volume of substrates did not affect the behavior of the cashew trees, as also observed by Correia et al. (2013) in eucalyptus seedlings when they verified that a higher volume of substrate provided the highest values for height and stem diameter at the level of the soil.

Dantas et al. (2013), when evaluating pineapple seedlings in different substrate volumes, observed that the volume of $2 \mathrm{~kg}$ was better than the $1 \mathrm{~kg}$ volume for the growth and dry matter characteristics of pineapple seedlings. For this reason, even if there is good availability of water, light and nutrients, dwarf cashew seedlings may have growth limited by container volume.

It was observed that the methods of breaking dormancy did not show significant effects; breaking dormancy with normal water for $24 \mathrm{~h}$ stood out over the scarification process with sandpaper for all analyzed variables, presenting an increase of 1.17, 1.17, and $4.60 \%$ in relation to breaking dormancy with normal water for root, shoot and total dry matter, respectively (Tab. 1). The data found in this research corroborate those of Menegazzo et al. (2013), who evaluated different methods of breaking dormancy and did not find satisfactory results for scarification.

Zuffo et al. (2014), when evaluating position and depth of sowing for emergence and initial development of Anacardium microcarpum Ducke seedlings, verified that the lowest depth provided the best result for dry root and shoot biomass at 1.84 and 2.93, lower than in the present research, 2.56 and 4.65, respectively.

Silva et al. (2015) found different results when analyzing chiseling as a method for breaking dormancy in terms of the initial growth of açai seedlings and noticed that mechanical scarification provided a higher percentage of emergence and development in the seeds.

The superior results with the application of the bovine biofertilizer indicate its effectiveness as a source of nutrients and organic matter, improving soil composition and supplying nutrients that are essential for increasing crop productivity without causing damage to the environment.

In addition, the higher values can also be attributed to the nutrient supply and increase of the biological activity of the soil that the bovine biofertilizer provided; therefore, the humic substances present in the bovine biofertilizer may have improved the substrate structure and, consequently, induced an increase in cell division and permeability of cell membranes, providing greater water and nutrient uptake in the cashew tree seedlings (Khaled and Fawy, 2011).

The increase in most of the analyzed variables may have been due to the improvement in the substrate composition, increasing the aeration of the substrate and allowing greater root growth; as a consequence, there was greater transport of water and mineral salts to the seedlings. In addition, some farmers have observed the effects of bovine biofertilizer on protecting plant roots from soil pathogens, improving soil fertility and increasing crop yield (Khaled and Fawy, 2011; Celedonio et al., 2013).

The maximum dose of bovine biofertilizer may have resulted in a higher nitrogen, phosphorus, potassium, calcium, magnesium, sulfur and micronutrient composition (Celedonio et al., 2013), which induced greater cell division and leaf expansion.

The application of bovine biofertilizer provided the highest values for growth, dry mass and quality of the cashew tree seedlings as a result of the improvement of the soil fertility with the bovine biofertilizer through the adsorption of exchangeable bases and the formation of organic complexes, besides developing negative loads (Silva et al., 2011). In addition, biofertilizer provides organic matter, with direct positive effects on soil, such as reduced compaction, increased water retention and improved nutrient availability (Pesakovic et al., 2013; Santos et al., 2017).

The data found for the DOI differed from those of Zuffo et al. (2014), who evaluated the position and depth of sowing in Anacardium microcarpum Ducke seedlings and found lower results, in which the highest values of the Dickson quality index (DOI) were found for the $2.0 \mathrm{~cm}$ sowing depth and when the positions of the nuts was thread down (A) and "back" up (E).

The higher values with the use of the $2 \mathrm{~kg}$ container was explained by the greater space for root growth and development of the cashew tree seedlings, improving root access to substrate moisture at depth, 
reducing stress resulting from the lack of water and, consequently, allowing higher growth (Stape et al., 2010) since the larger containers had a longer length, resulting in greater space for root growth and increasing the area of nutrient absorption.

\section{CONCLUSIONS}

The bovine biofertilizer doses of 7.5 and $10 \mathrm{~mL}$ provided higher growth and quality in the cashew tree seedlings.

The substrate volume of $2 \mathrm{~kg}$ was the most suitable volume for growing the cashew trees.

The method for breaking dormancy with normal water for $24 \mathrm{~h}$ was the most appropriate one for the formation of the cashew tree seedlings.

Conflict of interest: this manuscript was prepared and reviewed with the participation of all authors, who declare that there exists no conflict of interest that that puts in risk the validity of the presented results.

\section{ACKNOWLEDGMENT}

The authors thank the Conselho Nacional de Desenvolvimento Científico e Tecnológico (CNPq) and the Pro-Rectory for Graduate Studies and Research of the Universidade Estadual da Paraíba (UEPB) for the financial support given this research.

\section{BIBLIOGRAPHIC REFERENCES}

Aidyn, A., C. Kant, and M. Turan. 2012. Humic acid application alleviate salinity stress of bean (Phaseolus vulgaris L.) plants decreasing membrane leakage. Afr. J. Agric. Res. 7(7), 1073-1086. Doi: 10.5897/AJAR10.274

Alves, L.S., M.L.M Véras, J.S. Melo, T.H.S Filholrineu, and T.J. Dias. 2019. Salinidade na água de irrigação e aplicação de biofertilizante bovino no crescimento e qualidade de mudas de tamarindo. Irriga 4(2), 254-273. Doi: 10.15809/irriga.2019v24n2p254-273

Araújo, L.F., R.E. Lima, L.D.O. Costa, M. Ênio, and M.A. Bezerra. 2014. Alocação de íons e crescimento de plantas de cajueiro anão-precoce irrigadas com água salina no campo. Rev. Bras. Eng. Agríc. Ambient. 18(Suppl.), 34-38. Doi: 10.1590/1807-1929/agriambi. v18nsupps34-s38

Carvalho, M.B.F, M.E.R. Araujo, A.P. Mendonça, M.S. Chávez, K.L. Gutierrez, F.J.P. Ruiz, and A.P. Mocho.
2019. Métodos de superação de dormência da Schizolobium amazonicum Huber ex Ducke. Braz. J. Ani. Env. Res. 2(1), 490-500.

Cavalcante, L.F., F. Rodolfo Júnior, J.R. Sá, C.R.S. Curvelo, and E.F. Mesquita. 2007. Influência da água salina e matéria orgânica no desempenho do maracujazeiro amarelo e na salinidade do substrato. Irriga 12(4), 505518. Doi: 10.15809/irriga.2007v12n4p505-518

Cavalcante, L.F., G.F. Silva, H.R. Gheyi, T.J. Dias, J.C. Alves, and A.P.M. Costa. 2009. Crescimento de mudas de maracujazeiro-amarelo em solo salino com esterco bovino líquido fermentado. Rev. Bras. Ciênc. Agr. 4(4), 414-420. Doi: 10.5039/agraria.v4i4a7

Celedonio, C.A., J.F. Medeiros, F.L. Silva, K.R. Saraiva, and A.H.P. Albuquerque. 2013. Crescimento da figueira em três ambientes de cultivo, sob aplicação de biofertilizante bovino via fertirrigação. Rev. Bras. Agric. Irrig. 7(6), 358-370. Doi: 10.7127/rbai.v7n600195

Correia, A.C.G., R.C. Santana, M.L.R. Oliveira, M. Titon, G.M. Atáide, and F.P. Leite. 2013. Volume de substrato e idade: Influência no desempenho de mudas clonais de eucalipto após o plantio. Rev. Cerne 19(2), 185-191. Doi: 10.1590/S0104-77602013000200002

Costa, L.R., M.T. Gurgel, S.M. Alves, A.F. Mota, J. Azevedo, and J.P. Almeida. 2012. Crescimento de mudas de cajueiro anão precoce irrigado com efluente doméstico tratado. Rev. Bras. Ciênc. Agr. 7(3), 421-426. Doi: 10.5039/agraria.v7i3a1562

Costa, P.A., A.L. Silva Lima, F. Zanella, and H. Freitas. 2010. Quebra de dormência em sementes de Adenanthera pavonina L. Pesq. Agropec. Trop. 40(1), 83-88. Doi: 10.5216/pat.v40i1.4092

Dantas, G.F., W.L.D. Silva, M.D.A. Barbosa, E.F. Mesquita, and L.F. Cavalcante. 2013. Mudas de pinheira em substrato com diferentes volumes tratado com esterco bovino e biofertilizante. Agrarian 6(20), 178-190.

Dickson, A., A.L. Leaf, and J.F. Hosner. 1960. Quality appraisal of white spruce and white pine seedling stock in nurseries. Forest Chron. 36(1), 10-13. Doi: 10.5558/ tfc36010-1

Diniz, M.B.V.S., E.F. Mesquita, F.V.S. Sá, E.P. Paiva, J.F.V. Diniz, and C.F. Suassuna. 2015. Crescimento de porta-enxertos de goiabeira influenciado por doses de biofertilizante, tipo e volume de substrato. Científica 43(2), 165-178. Doi: 10.15361/1984-5529.2015v43n $2 \mathrm{p} 165-178$

Dutra, K.O.G., T.H.S. Irineu, M.L.M. Véras, J.P. Figueredo, J.N. Silva, R. Andrade, and C.H.S.G. Meneses. 2018. Biochemical alterations of red rice cultivated at soil water levels and organomineral fertilization. Com. Sci., 9(2), 185-193. Doi: 10.14295/cs.v9i2.2111

Ferreira, D.F. 2014. Sisvar: a guide for its bootstrap procedures in multiple comparisons. Ciênc. Agr. 38(2), 1092012. Doi: 10.1590/S1413-70542014000200001 
Khaled, H. and H.A. Fawy. 2011. Effect of different levels of humic acids on the nutrient content, plant growth, and soil properties under conditions of salinity. Soil Water Res. 6(1), 21-29. Doi: 10.17221/4/2010-SWR

Mata, M.F., A.F. Frota, and E.U. Alves. 2010. Superação da dormência de sementes de chichá (Sterculia striata A. St. Hil. \& Naudin.) Malvaceae - Sterculioideae. Rev. Homem, Espaço e Tempo 1(4), 214-232.

Melo Filho, J.S., M.L.M. Véras, T.I. Silva, L.S. Alves, and T.J. Dias. 2018. Organic fertilizers as mitigating effects of water salinity on Passiflora cincinnata seedlings. Acta Agron. 67(4), 501-511. Doi: 10.15446/acag. v67n 4.69475

Menegazzo, M.L., S.M. Kulczynski, A.C. Oliveira, and E.A. Silva. 2013. Produção de mudas de pinha em diferentes recipientes utilizando métodos de superação de dormência em sementes. Agrarian 6(20), 121-129.

Mesquita, F.D.O., A.M. Rebequi, L.F. Cavalcante, and A. G.D.L. Souto. 2012. Crescimento absoluto e relativo de mudas de maracujazeiro sob biofertilizante e águas salinas. Rev. de Ciênc. Agr. 35(1), 222-239.

Paiva, J.R.G., F. Silva, L.L. Ferreira, E.F. Mesquita, and V.C.N. Porto. 2013. Produção de mudas de pinheira (Annona Squamosa L.) em função da adubação orgânica e volumes de substrato. Cad. Agroec. 8(2), 1-5.

Peixoto, C.P. and M.F.S.P. Peixoto. 2009. Dinâmica do crescimento vegetal: princípios básicos. Tópicos Ciênc. Agrár. 1, 37-53.

Pesakovic, M., K.S. Stajic, M. Slobodan, and M. Olga. 2013. Biofertilizer affecting yield related characteristics of strawberry (fragaria $\times$ ananassa duch.) and soil micro-organisms. Sci. Hortic. 150(4), 238-243. Doi: 10.1016/j.scienta.2012.11.016

Sá, F.V.S., M.E.B. Brito, A.S. Melo, P. Antonio Neto, P.D. Fernandes, and I.B. Ferreira. 2013. Produção de mudas de mamoeiro irrigadas com água salina. Rev. Bras. Eng. Agríc. Ambient. 17(10), 1047-1054. Doi: 10.1590/ S1415-43662013001000004

Santos, H.G., P.K.T. Jacomine, L.H.C. Anjos, V.A. Oliveira, J.F. Lumbreras, M.R. Coelho, J.A. Almeidade, T.J.F. Cunha, and J.B. Oliveira. 2013. Sistema brasileiro de classificação de solos. $3^{\text {th }}$ ed. Embrapa, Brasília.

Santos, E.O., E.D.O. Santos, T.V.D.A. Viana, G.G.D. Sousa, A.C.P.P.D. Carvalho, and B.M.D. Azevedo. 2017. Biomass accumulation and nutrition in micropropagated plants of the banana 'prata catarina' under biofertilisers. Rev. Caatinga 30(4), 901-911. Doi: 10.1590/1983-21252017v30n410rc

Silva, F.L.B., C.F. Lacerda, G.G. Sousa, A.L. Neves, G.L. Silva, and C.H. Sousa. 2011. Interação entre salinidade e biofertilizante bovino na cultura do feijão-de-corda. Rev. Bras. Eng. Agríc. Ambient. 15(4), 383-389. Doi: 10.1590/S1415-43662011000400009

Silva, J.A., A.P. Oliveira, G.S. Alves, L.F. Cavalcante, A.N.P. Oliveira, and A.M.A. Maria. 2012. Rendimento do inhame adubado com esterco bovino e biofertilizante no solo e na folha. Rev. Bras. Eng. Agríc. Ambient. 16(3), 253-257. Doi: 10.1590/S1415-43662012000300003

Silva, E.M., M.C. Parreira, S.C. Siebeichler, E. Rodrigues, C.M.S. Santos, F.D.C.V. Neto, and Freitas. 2019. Produção de mudas de Cajueiro Anão-precoce em substratos de resíduos orgânico. Rev. Bras. Agropec. Sust. 9(1), 90-96. Doi: 10.21206/rbas.v9i1.7969

Silva, L.L., H.E.L. Primo, O.J. Smiderle, E.A. Chagas, and A. Graças Souza. 2015. Escarificação de sementes para desenvolvimento em plântulas de açaizeiro. Rev. Agro@mbiente 9(1), 72-78. Doi: 10.5327/ Z1982-8470201500011909

Stape, J.L., D. Binkley, M.G. Ryan, S. Fonseca, R.A. Loos, E.N. Takahashi, C.R. Silva, S.R. Silva, R.E. Hakamada, J.M.A. Ferreira, A.M.N. Lima, J.L. Gava, F.P. Leite, H.B. Andrade, J.M. Alves, G.G.C. Silva, and M.R. Azevedo. 2010. The Brazil eucalyptus potential productivity project: influence of water, nutrients and stand uniformity on wood production. Forest Ecol. Manag. 259, 1684-1694. Doi: 10.1016/j.foreco.2010.01.012

Torres, E.C.M., J.L.O. Freire, J.L. Oliveira, L.B. Bandeira, D.A. Melo, and A.L. Silva. 2014. Biometria de mudas de cajueiro anão irrigadas com águas salinas e uso de atenuadores do estresse salino. Nativa 2(2), 71-78. Doi: $10.14583 / 2318-7670 . v 02$ n02a03

Ursulino, M.M., E.U. Alves, P.C. Araújo, M.M. Alves, T.D.S. Ribeiro, and R.D.S. Silva. 2019. Superação de dormência e vigor em sementes de Fava-d'Anta (Dimorphandra gardneriana Tulasne). Ciênc. Fl. 29(1), 105-115. Doi: 10.5902/1980509810460

Veras, M.L.M., D.L. Araújo, G.G. Silva, J.S. Melo Filho, and R. Andrade. 2014. Efeito do biofertilizante e de volumes de substrato no desenvolvimento de mudas de caju. Rev. Verde de Agroec. e Desenv. Sust. 9(2), 324-332.

Viana, T.V.A., A.P.G. Santos, G.G. Sousa, L.G. Pinheiro Neto, B.M. Azevedo, and B.F. Aquino. 2013. Trocas gasosas e teores foliares de NPK em meloeiro adubado com biofertilizantes. Rev. Bras. Ciênc. Agr. 8(4), 595 601. Doi: 10.5039/agraria.v8i4a3260

Zuffo, A.M., F.R. Andrade, F.A. Petter, T.R. Souza, and A.C. Piauilino. 2014. Posição e profundidade de semeadura na emergência e desenvolvimento inicial de mudas de Anacardium microcarpum Ducke. Rev. Bras. Ciênc. Agr. 9(4), 556-561. Doi: 10.5039/agraria.v9i4a2721 